\title{
One side makes you taller: a mushroom-eating butterfly caterpillar (Lycaenidae) in Costa Rica
}

\author{
Kenji Nishida ${ }^{1}$, Robert K. Robbins ${ }^{2}$ \\ 1 Collaborator, Museo de Zoología, Universidad de Costa Rica; and Estación Biológica Monteverde, \\ Monteverde, Puntarenas, Costa Rica \\ 2 Department of Entomology, Smithsonian Institution, Washington, DC, USA \\ Corresponding author: Robert K. Robbins (robbinsr@si.edu)
}

Academic editor: P. Nunes-Silva | Received 25 August 2020 | Accepted 13October 2020| Published 11 November 2020

Citation: Nishida K, Robbins RK (2020) One side makes you taller: a mushroom-eating butterfly caterpillar (Lycaenidae) in Costa Rica. Neotropical Biology and Conservation 15(4): 463-470. https://doi.org/10.3897/ neotropical.15.e57998

\begin{abstract}
Electrostrymon denarius is the first mushroom-feeding butterfly caterpillar discovered in the New World. It belongs to the Calycopidina, a subtribe of lycaenid butterflies whose caterpillars eat detritus and seeds in the leaf litter. Electrostrymon denarius has not been reared previously, and we illustrate and briefly describe the biology and morphology of its caterpillar and pupa. The significance of this discovery is that it increases the range of organic leaf litter substrates that Calycopidina caterpillars will eat. Increased diet breadth may decrease the likelihood of species extinction.
\end{abstract}

\section{Keywords}

Detritivory, Electrostrymon, Eumaeini, immature stages, life history, Polyporus

\section{Introduction}

The seminal paper on insect-plant coevolution (Ehrlich and Raven 1965) summarized the wide variety of Angiosperms and Gymnosperms that butterfly caterpillars eat. In the New World, however, a few species are predacious (Youngsteadt and DeVries 2005; Mota et al. 2020), several species eat lycopsids/mosses (Singer et al. 1971; Singer and Mallet 1986; Hamm and Fordyce 2016; Freitas et al. 2019), and about 200 species feed on leaf litter detritus (Hall and Harvey 2001; Duarte and 
Robbins 2010). Despite the popular cultural association of caterpillars with mushrooms in Lewis Carrol's Alice in Wonderland, no New World butterfly caterpillars have been reported to eat fungus. In Africa, the largely endemic Lipteninae (Lycaenidae, sensu Eliot 1973) feed on epiphylls (Callaghan 1992; Bampton 1995), but whether they specifically eat mushrooms (the fruiting body of a fungus) does not appear to have been addressed.

The purpose of this paper is to report a Costa Rican mushroom-feeding caterpillar of Electrostrymon denarius (Butler and H. Druce) in the lycaenid subtribe Calycopidina (Theclinae) (Figs 1-15). The caterpillar was eating a mushroom in nature and completed development on it. Its life history was previously unrecorded. We illustrate and briefly describe the biology and morphology of its caterpillar and pupa. The significance of this report is that it increases the range of organic leaf litter substrates that Calycopidina caterpillars will eat.

\section{Materials and methods}

This study was conducted at Estación Biológica Monteverde (EBM), a part of Tilarán Mountain Range, Puntarenas Province, Costa Rica, from May 20, 2017 to June 11,2017. EBM is a private biological research station consisting of about 120 hectares of primary and secondary forest (Fig. 4) and elevation ranging from approximately 1,500 to $1,800 \mathrm{~m}$. The exact study site is located on the Pacific slope at $10^{\circ} 19^{\prime} 07^{\prime \prime} \mathrm{N}, 084^{\circ} 48^{\prime} 29^{\prime \prime} \mathrm{W}$ and $1530 \mathrm{~m}$ elevation at the station building area. Life zone ecology is lower mountain wet forest, with a mean annual rainfall of about $4000 \mathrm{~mm}$ and mean annual temperature of $17^{\circ} \mathrm{C}$ (Bolaños and Watson 1993). The general vegetation type is 'perpetually dripping cloud forest', characterized by diverse and abundant epiphytes and epiphylls, dense understory shrubs, tree saplings, large herbs, and abundant fallen leaves on the forest floor (Haber 2000) (Fig. 5). The climate is tropical temperate humid (Herrera-Soto and Gómez-Pignataro 1993). The rainy season with typical afternoon thunder showers lasts from mid-May to November. December to February is a transition to the dry season with strong trade winds accompanied by drizzle and mist. Late February to mid-April is dry.

The caterpillar ( $\mathrm{n}=1$ ) (Fig. 7) was collected with the 'host' mushroom (Fig. 6) and placed inside a white mesh net, along with fallen dried leaves (Fig. 8). The mesh net was placed where the caterpillar was originally found. It was covered with a slotted black plastic bin and a large rock (Fig. 9) to avoid disturbance from wild animals such as white-nosed coati (Nasua narica). The caterpillar was observed at least once a day to document development. The head capsule and pupal shell were preserved in $75 \% \mathrm{EtOH}$. The emerged adult was pinned, spread, and dried as a voucher specimen. Measurements were made with a digital caliper and ruler. Images were recorded with an Olympus Tough TG-4, OM-D E-M1 Mark II with a $60 \mathrm{~mm}$ macro lens and Canon EOS 7D Mark II with a $100 \mathrm{~mm}$ macro lens for close-up images. A Sony DSC-RX100IV was used for habitat photos. Images were processed and edited by Adobe Lightroom Classic and Photoshop software. 

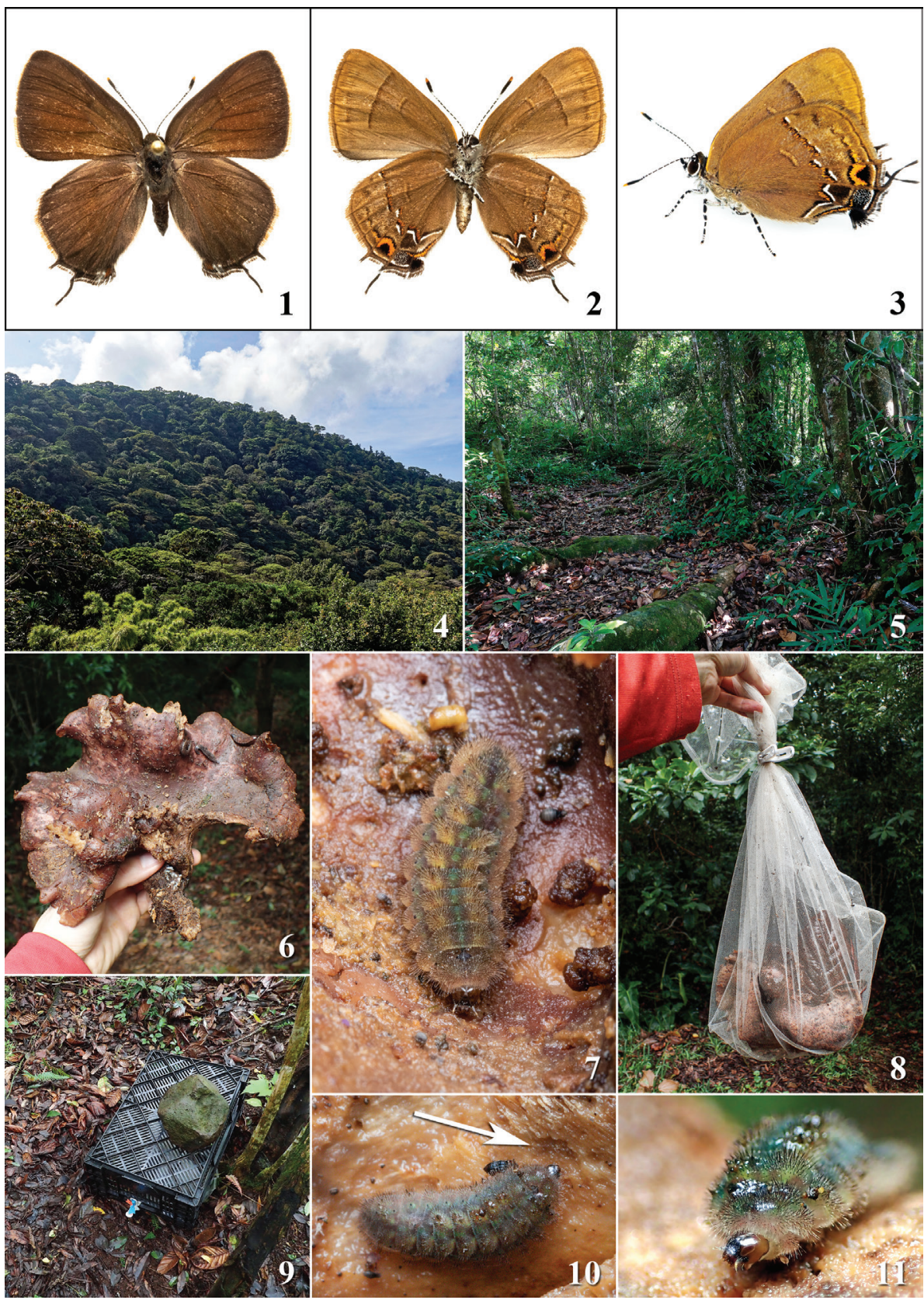

Figures 1-11. Life history of Electrostrymon denarius and study site 1. Reared adult female, dorsal view, forewing length $13 \mathrm{~mm}$. 2. Reared adult female, ventral view. 3. Live reared adult female on white, flat surface. 4. Cloud forest mountain habitat at EBM. 5. Habitat showing forest floor. 6. "Host" Polyporus mushroom. 7. Last instar (ca. $12 \mathrm{~mm}$ long) on mushroom (dorsal view). 8. Rearing mesh net with mushroom and fallen dried leaves inside. 9. Rearing conditions showing mesh net protected with black basket and a rock on top (white clip with orange and blue tape on basket is for marking). 10. Mature caterpillar on mushroom, arrow pointing where caterpillar fed. 11. Close-up of head and thoracic segments (dorso-latero-frontal view). 


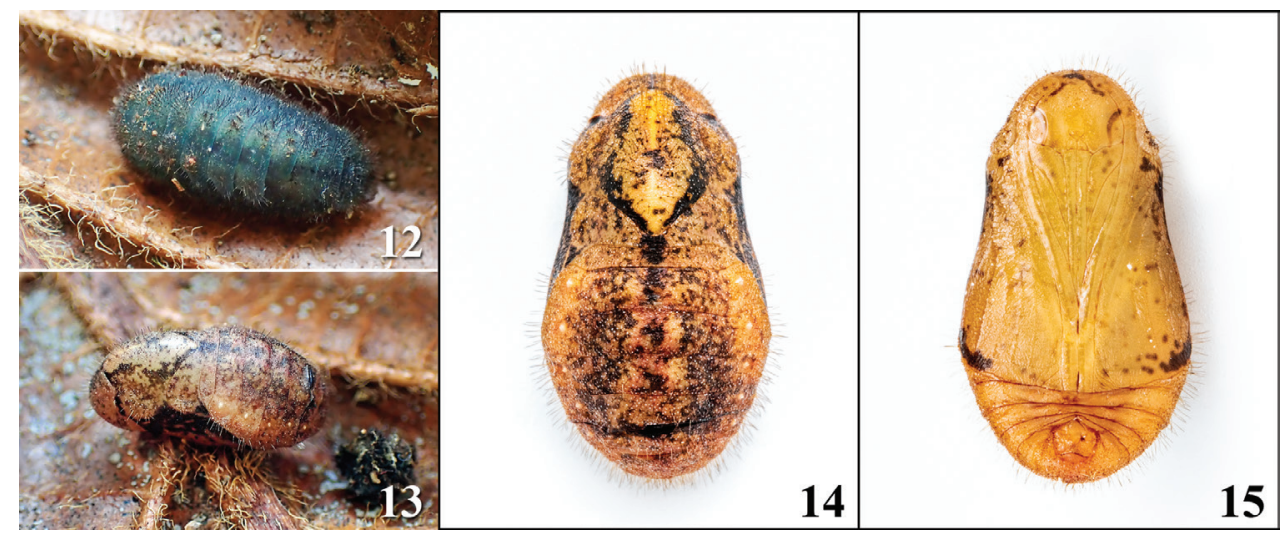

Figures 12-15. Life history of Electrostrymon denarius. 12. Mature caterpillar in its 'pre-prepupal' stage (dorso-latero-caudal view) on a dried leaf. 13. Pupa, ca. $8 \mathrm{~mm}$ long, dorso-lateral view, caterpillar skin (bottom right). 14. Pupa, dorsal view. 15. Pupa, ventral view.

The reared adult, caterpillar pelt with head capsule, and pupal shell are deposited in Museo de Zoología, Universidad de Costa Rica, San José, Costa Rica (MZUCR).

\section{Results}

\section{Description and biology of immatures}

Last instar of Electrostrymon denarius (Figs 7, 10-12) about $12 \mathrm{~mm}$ long, head small, frons and stemmatal area black, epicranium brown, antennae long and pale brown to white; body pinkish pale brown with three longitudinal greenish gray lines mesially and laterally, covered with black to dark brown, short, bristle-like setae (laterally with some white to pale brown setae), spiracles black. Body shape of 'Pre-prepupal' caterpillar stage, ellipsoid and coloration became bluish-green gray (Fig. 12). Pupa (Figs 13-15) about $8 \mathrm{~mm}$ long, body pale brown mottled with dark brown areas (especially on dorsum, thorax, wing sclerite, and abdomen), covered with fine and short dark to pale brown setae dorsally to latero-ventrally except wing sclerite, spiracles white. Overall color of pupa became dark a day prior to adult eclosion.

The caterpillar of Electrostrymon denarius was found eating a fallen, relatively large, and decaying Polyporus mushroom on 20 May 2017 on the ground in shaded area of the forest edge (Figs 6-8, 10, 11, Suppl. material 1: Video). Slugs and small beetles of different kinds were also eating the mushroom (cf. Schigel 2012 for a review of mycophagous beetles), but no interaction was noted between them and the caterpillar. The caterpillar fed only on the mushroom. On 27 May 2017, it moved to a dried leaf (Fig. 12), appeared to stop feeding, turned a more bluish color, and became more ellipsoid-. The caterpillar pupated on the same dead leaf on 29 May 2017 (Figs 13-15). No cremaster-silk substrate or silk girdle was observed. The pupa was not attached to the dried leaf. An adult female eclosed 11 June 2017 (Fig. 3). 


\section{Discussion}

Electrostrymon denarius belongs to the New World lycaenid butterfly subtribe Calycopidina, which consists of ten genera with about 175 species (Duarte and Robbins 2010). Calycopidine females lay eggs in the leaf litter on dead leaves, twigs, and fallen flowers (S. Johnson 1985; Duarte and Robbins 2010; Robbins et al. 2010). Caterpillars complete development on dead leaves and fallen flowers; occasionally on other dead plant matter (Duarte and Robbins 2010; Robbins et al. 2010). Two Calycopidina genera, Lamprospilus Geyer and Ziegleria Johnson, were recently recorded eating seeds in the leaf litter (Gripenberg et al. 2019). Now a species has been recorded feeding on a mushroom, increasing the breadth of leaf litter organic matter that these butterflies eat. Detritivores help accelerate decomposition and nutrient cycling of the ecosystem.

Electrostrymon denarius belongs more specifically to the Electrostrymon guzanta species group, which is a highly apomorphic lineage of four species with indistinguishable male primary and secondary sexual structures (Duarte and Robbins 2010; Thompson and Robbins 2016). It occurs from the southern United States to Venezuela and Colombia, and each species is allopatric or elevationally parapatric with the others (Thompson and Robbins 2016). Electrostrymon denarius is the most widespread species in the E. guzanta species group. It occurs from 50 to $1,750 \mathrm{~m}$ elevation from Mexico to Panama. In Costa Rica, it is parapatric with E. thurman (Thompson and Robbins 2016).

Electrostrymon guzanta is the only other member of this species group to be reared previously. It was lab-raised by Nick Grishin (pers. comm.), who fed the caterpillars mulberry leaves that were available. The immature stages are illustrated (http://www.butterfliesofamerica.com/electrostrymon_guzanta_immatures.htm, accessed 11 Aug 2020). Not surprisingly, the immatures resemble those of $E$. denarius, but we lack preserved specimens for a more detailed morphological comparison. A reared adult voucher of E. guzanta was deposited in the Smithsonian Institution (USNM), Washington, DC, USA. Whether the caterpillar would have eaten mushrooms in nature is an open question.

Fungus-eating has evolved repeatedly in the Lepidoptera, usually in lineages containing detritivores (Rawlins 1984). Litter feeding detritivores, such as the caterpillars in the Calycopidina, might be expected to be chronically exposed to fungi growing in the leaf litter. Major switches to a new food are often associated with chronic exposure of caterpillars to the new food, as hypothesized in switches to lycopsids/mosses and to mistletoes (Singer et al. 1971; Chew and Robbins 1984).

A leaf litter feeding habit in the Calycopidina contrasts with other Eumaeini, which eat Angiosperms or Gymnosperms. With hundreds of Neotropical Eumaeini scientifically undescribed (Robbins 2004), authoritative conservation status reports are yet premature. However, the first attempts to codify status (Brown 1993) showed that many Neotropical Eumaeini of conservation concern eat green plants that are 
habitat restricted. If these preliminary findings are sustained, an evolutionary switch to eating a wide variety of ubiquitous leaf litter organic matter would potentially lower extinction vulnerability.

\section{Acknowledgments}

We thank Julieta Carranza of Universidad de Costa Rica for identifying the fungus. We are grateful to Annette Aiello, André Freitas, Elizabeth Heffington, and Marcelo Duarte for commenting on the manuscript. For sharing information and ideas, we thank Curtis Callahan, Nick Grishin, Winnie Hallwachs, Dan Janzen, Luisa Mota, and Thamara Zacca.

\section{References}

Bampton I (1995) A discussion on the larval food of the subfamily Lipteninae (Lepidoptera, Lycaenidae). Metamorphosis 6: 62-166.

Bolaños RA, Watson V (1993) Mapa ecológico de Costa Rica. Centro Científico Tropical, San José, Costa Rica. [map]

Brown Jr KS (1993) Selected Neotropical species. In: New TR (Ed.) Conservation Biology of Lycaenidae Butterflies IUCN, Gland, Switzerland, 146-149.

Callaghan CJ (1992) Biology of epiphyll feeding butterflies in a Nigerian cola forest (Lycaenidae: Lipteninae). Journal of the Lepidopterists Society 46: 203-214.

Chew FS, Robbins RK (1984) Egg-laying in butterflies. In: Vane-Wright RI, Ackery PR (Eds) The Biology of Butterflies. Symposium of the Royal Entomological Society of London 11: 65-79.

Duarte M, Robbins RK (2010) Description and phylogenetic analysis of the Calycopidina (Lycaenidae, Theclinae, Eumaeini): A subtribe of detritivores. Revista Brasileira de Entomologia 54(1): 45-65. https://doi.org/10.1590/S0085-56262010000100006

Ehrlich PR, Raven PH (1965) Butterflies and plants: A study in coevolution. Evolution; International Journal of Organic Evolution 18(4): 586-608. https://doi. org/10.1111/j.1558-5646.1964.tb01674.x

Eliot JN (1973) The higher classification of the Lycaenidae (Lepidoptera): A tentative arrangement. Bulletin of the British Museum (Natural History). Entomology 28: 371-505. https://doi.org/10.5962/bhl.part.11171

Freitas AVL, Mota LL, Barbosa EP, Carreira JYO (2019) Immature stages of the Selaginella -feeding Euptychia mollina (Nymphalidae: Satyrinae) from the Brazilian Amazon. Zoologia (Curitiba) 36: e32053. EpubJune132019. https://doi.org/10.3897/zoologia.36.e32053

Gripenberg S, Basset Y, Lewis OT, Terry JCD, Wright SJ, Simón I, Fernandez DC, Cedeño M, Rivera M, Barrios H, Brown JW, Calderón O, Cognato AI, Miller S, Morse GE, PinzonNavarro S, Quicke DLJ, Robbins RK, Salminen J, Eero Vesterinen E (2019) A highlyresolved food web for insect seed predators in a species-rich tropical forest. Ecology Letters. https://doi.org/10.1111/ele.13359 
Haber WA (2000) Appendix 1, Vascular plants of Monteverde. Monteverde, ecology and conservation of a tropical cloud forest. Oxford University Press, New York, 573 pp.

Hall JPW, Harvey DJ (2001) A phylogenetic revision of the Charis gynaea group (Lepidoptera: Riodinidae) with comments on historical relationships among Neotropical areas of endemism. Annals of the Entomological Society of America 94(5): 631-647. https://doi. org/10.1603/0013-8746(2001)094[0631:PROTCG]2.0.CO;2

Hamm CA, Fordyce JA (2016) Selaginella and the satyr: Euptychia westwoodi (Lepidoptera: Nymphalidae) oviposition preference and larval performance. Journal of Insect Science 16(1): 1-39. https://doi.org/10.1093/jisesa/iew018

Herrera-Soto W, Gómez-Pignataro LD (1993) Mapa de unidades bióticas de Costa Rica. Escala 1:685.000. US Fish and Wildlife Service, TNC, INCAFO, CBCCR, INBio, Fundación Gómez-Dueñas. San José, Costa Rica. [map]

Johnson SA (1985) Culturing a detritivore, Calycopis isobeon (Butler \& Druce). News of the Lepidopterists' Society 3: 41-42.

Mota LL, Kaminski LA, Freitas AVL (2020) The tortoise caterpillar: carnivory and armoured larval morphology of the metalmark butterfly Pachythone xanthe (Lepidoptera: Riodinidae). Journal of Natural History 54(5-6): 5-6. [309-319.] https://doi.org/10.1080/00 222933.2020.1759720

Rawlins JE (1984) Mycophagy in Lepidoptera. In: Wheeler Q, Blackwell M (Eds) Fungusinsect Relationships. Columbia University Press, 382-423.

Robbins RK (2004) Introduction to the checklist of Eumaeini (Lycaenidae). In: Lamas G (Ed.) Checklist: Part 4A. Hesperioidea - Papilionoidea. In: Heppner JB (Ed.) Atlas of Neotropical Lepidoptera (Vol. 5A). Association for Tropical Lepidoptera, Scientific Publishers, Gainesville, xxiv-xxx.

Robbins RK, Aiello A, Feinstein J, Berkov A, Caldas A, Busby RC, Duarte M (2010) A tale of two species: detritivory, parapatry, and sexual dimorphism in Lamprospilus collucia and L. orcidia (Lycaenidae: Theclinae: Eumaeini). Journal of Research on the Lepidoptera 42: 64-73.

Schigel DS (2012) Fungivory and host associations of Coleoptera: A bibliography and review of research approaches. Mycology 3: 258-272. https://doi.org/10.1080/21501203.2012. 741078

Singer MC, Mallet J (1986) Moss-feeding by a satyrine butterfly. Journal of Research on the Lepidoptera 24: 392.

Singer MC, Ehrlich PR, Gilbert LE (1971) Butterfly feeding on Lycopsid. Science 25(3990): 1341-1342. https://doi.org/10.1126/science.172.3990.1341

Thompson PM, Robbins RK (2016) Allopatry and parapatry in hairstreak butterflies (Lycaenidae, Eumaeini) with uniform male sexual structures. Journal of Research on the Lepidoptera 14: 53-68.

Youngsteadt E, DeVries PJ (2005) The effects of ants on the entomophagous butterfly caterpillar Feniseca tarquinius, and the putative role of chemical camouflage in the Fenisecaant interaction. Journal of Chemical Ecology 31(9): 2091-2109. https://doi.org/10.1007/ s10886-005-6079-2 


\section{Supplementary material 1}

One side makes you taller: a mushroom-eating butterfly caterpillar (Lycaenidae) in Costa Rica

Authors: Kenji Nishida, Robert K. Robbins

Data type: $\mathrm{m} 4 \mathrm{v}$ video

Explanation note: Caterpillar of Electrostrymon denarius eating a Polyporus mushroom.

Copyright notice: This dataset is made available under the Open Database License (http://opendatacommons.org/licenses/odbl/1.0/). The Open Database License $(\mathrm{ODbL})$ is a license agreement intended to allow users to freely share, modify, and use this Dataset while maintaining this same freedom for others, provided that the original source and author(s) are credited.

Link: https://doi.org/10.3897/neotropical.15.e57998.suppl1 